\title{
Evaluating Pragmatic Competence in Nigerian Undergraduates' Language Errors within Descriptive ESL Writing
}

Anas Sa'idu Muhammad

PhD Student, AHSGS, Universiti Utara, Malaysia, muhammadas1982@gmail.com

Subadrah Madhawa Nair

Department of Languages, SEML, Universiti Utara, Malaysia, subadrah@uum.edu.my

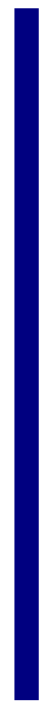

This study investigates the level of pragmatic competence for ESL writing skills among Nigerian undergraduates. Methodologically, it adopts descriptive research design within the explanatory framework of the QUAN-Qual model. The instruments used are descriptive essay text and focus group interview questions. In writing the descriptive essays, a total of 402 undergraduates' participated through convenience sampling. Quantitatively, an independent samples t-test was carried out. The results indicated the females required putting more efforts towards improving their pragmatic competence in the ESL writing as they achieved a higher means for language errors, compared to that of the males. Moreover, the ttest value demonstrated that the females lacked skills in the pragmatic skills of mechanical structure, grammatical function, and sentence structures and this made them commit more language errors. Qualitatively, a focus group interview was held randomly with 12 participants out of the 402 undergraduates through purposive sampling. The results of the interview sessions revealed novelties of culture-specific, learning feasibility and the academic discourse as the key elements that constraint most of the Nigerian undergraduates ESL writing skills, particularly the females. Therefore, this study revealed strong implications on how best to develop Nigerian learners' pragmatic competence in ESL writing skills.

Key Words: ESL writing, pragmatic competence, gender variation, language errors, Nigerian undergraduates, descriptive essay writing

\section{INTRODUCTION}

In this study, the system of attaining thriving writing skills among ESL learners is established by encompassing mastery in the use of the approaches to pragmatic competence, which is aptly required to make up a less erroneous writing (Garba, 2013; Grabe \& Kaplan, 2014; Leech, 1983; Williams, 2005). Ironically, past studies have established that the majority of ESL learners do not fare well to pragmatic competence in ESL writing skills (Abegunde, 2014; Bdliya, 2014; Ifantidou, 2014; Mojabi, 2014). These works affirm that the majority of the ESL learners' face significant challenges in 
the areas of mechanical, grammatical, and sentence formations. This signifies the level of critical requirement on them to develop their pragmatic competence in ESL writing.

In a fairly obvious sense, pragmatic competence stands as a major attribute that plays crucial roles in the development of ESL learners' writing competence, particularly in academic situations. At length, studies have indicated that in both ESL/EFL contexts, learners' often commits language errors and are not sufficient enough with competence and proficiency to produce a skilled ESL writing (Adogwa, 1992; Cui \& Tae-Ja, 2013). However, the explorations of studies within such scope seem to very limited, which is made to be assumed as less important. Basically, it is evident that Chomsky (1965), Hymes (1972), Gumperz and Cook-Gumperz (1982), Leech (1983), Seville-Troike (2003), and Ifantidou (2014), extensively express their views on the learners' difficulties towards producing accurate grammatical, communicative, strategic, and proficient use of language. This, which they affirm, often depends on certain sociological factors. As an instance of this scenario, Figure 1. highlights Leech's tradition of pragmatic competence, which often creates sensitivity to learners' appropriate convention of language use according to the grammatical and sociological features.

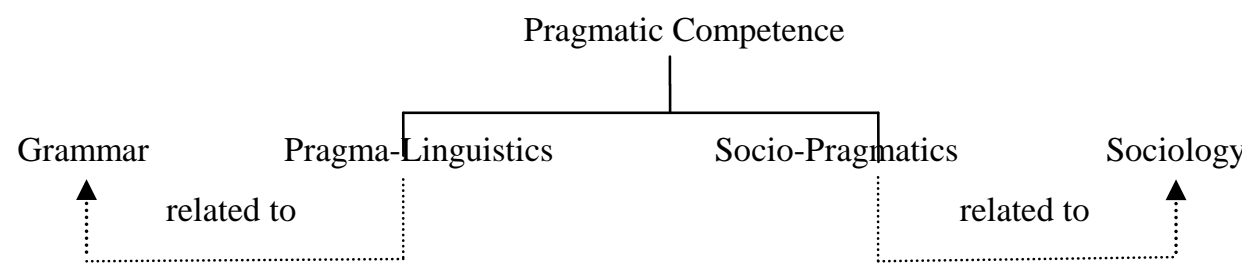

Figure 1

An adapted Leech's (1983) principles of pragmatic competence model

From figure 1.1, it can be observed that a number of sociological factors have been credited as the causative agents of language errors associated with students' lack of competence in term of pragmatic development. And this model is heavily linked and as well related to this study in investigating Nigerian undergraduate's pragmatic competence in ESL writing skills. More importantly, in considering the discrepancies of ESL writing among L2 learners, Crystal (1985) associated pragmatic competence to "languages use from the point of difficulties in terms of language choice and the constrain learners encountered in the act of communicating events" (p. 240).

To examine the possible role of pragmatic competence in ESL writing, this study, from its reviews found that Nigerian undergraduates are heavily vulnerable to gender variant; as one of the core socio-pragmatic factors. To make the matter worse, it found, studies relating to pragmatic competence in ESL/EFL writing, both globally and nationally, are relatively scarce and are very rare, as researchers mostly concentrate on the spoken context (Mojabi, 2014; Okunrinmeta, 2014). With this, we found that there are very limited studies conducted to realise the pragmatic competence of ESL writing precisely, among Nigerian undergraduates as it is aimed in this study. Considering this circumstance, we endeavour to investigate the pragmatic competence among Nigerian undergraduates' in descriptive ESL writing, so as to fill such gap. Getting aware of these 
deficiencies, it furnishes us with the sources of the students' language errors and to recommend therapeutic approaches that could help in minimising their errors in ESL writing.

\section{Research Objectives}

The main objective of this study is to investigate the level of Nigerian undergraduates' pragmatic competence in ESL writing skills. This study is situated within the scope of gender variance so as to provide justifiable limitations to its statistical and qualitative analysis. This is certainly to the fact; studies on the male and the female ESL learner's variation have derived attention of various scholars and it remains inconclusive due to certain socio-pragmatic issues (Abegunde, 2014; Babalola \& Oyinloye, 2012; Francis, 2015; Kamal, 2004). Using this focus, it provides us with the reflection that focuses and elicits the variation between the Nigerian male and female undergraduates in their ESL writing. Specifically, their variation in terms of language errors in the areas of grammar, sentence and mechanical structures were significantly identified. The central idea is that the identified statistical results further provides us with an extension of socio-pragmatic factors that constraints the ESL writing discourse of either Nigerian male and female undergraduates' pragmatic competence through qualitative data analysis.

\section{Research Questions}

In this study, following the research objectives, we set to answer the following research questions:

i. Is there any significant difference in the overall mean score for language errors found in the undergraduate students' ESL writing according to gender?

ii. Is there any significant difference for language errors found in the use of mechanical structure in students' ESL writing according to gender?

iii. Is there any significant difference for language errors found in the use of grammatical functions in students' ESL writing according to gender?

iv. Is there any significant difference for language errors found in the use of sentence structures in students' ESL writing according to gender?

$\mathrm{v}$. What are the factors that made the majority of the Nigerian undergraduates to the lack of pragmatic competence, which facilitates their language errors in ESL writing?

\section{LITERATURE REVIEW}

Primarily, writing competence in accordance with gender variation in an ESL situation has been incorporated and investigated in the learning instruction, and has proved to be in great contrast (Mojabi, 2014; Sarfraz, 2011). On this basis, keeping within the lane of the Nigerian context, results from the past studies statistically reveals that average Nigerian undergraduates are found to be pragmatically less competent in ESL writing (Babalola \& Oyinloye 2012; Bodunde \& Sotiloye 2013). It has been established that the majority of the Nigerian undergraduates finds it critical to attaincompetency and to produce less erroneous ESL writing. However, within the nooks and crannies of the 
Nigerian contexts, competence within the pragmatic scale of ESL writing is very much vital. Because as an ESL discourse community, pragmatic competence in ESL writing remains critical and is in high demand, in their academic, daily affairs, and even in their future administrative tests. Precisely, from the literature reviews, we get to know, the majority of the Nigerian ESL learners at the university level are yet to master the required pragmatic skills necessary for an ESL writing competence.

To an extent, it is apparently difficult and it is evidently troublesome for the larger part of the Nigerian ESL learners to produce a piece of writing with an exact grammatical, structural and mechanical features. In essence, in a prior study conducted by Adogwa (1992), three broad classes of language errors, namely; structural, grammatical and mechanical errors were revealed as the most persistent deficiencies in terms of pragmatic development among Nigerian undergraduates. With this, he implied that the one year of formal English instruction (Comskip) which was at that time taught to undergraduates at their 100 level did not essentially yielded the desired students' competence in ESL writing.

Indeed and exclusively within the domain of the Nigerian perspectives, Ojetunde (2013) explicated that at least a total of 227 errors were identified in an examined ESL writing of Nigerian ESL learners. He makes known that $81.06 \%$ were in the area of grammar, in the use of static and deviant verbs, deviant use of pronouns, deviant use of prepositions, use of redundant plural noun forms, the omission of function words, over the use of modifiers and the over generalisation of morphological rules. While $18.94 \%$ were for errors in the use of sentences in terms of semantic extension, semantic transfer, and aspect of word coinage. However, none of these studies have attempted to investigate this important phenomenon of perceiving the level of Nigerian undergraduates' variation in terms of pragmatic competence in ESL writing skills as proposed in this study.

In another related study with divergent findings, Ololube, Agbor and Uriah (2013) attributed that Nigerian students' failures in ESL writing was due to their indulgence in activities relating to unionism and or mystery cliques. To the extent, undergraduates believed that such activity would facilitate their academic credibility, not necessary for them to culminate the habit of perfecting their pragmatic skills. The researchers argued, such an attitude raised the bar for examination malpractice, the dearth of qualified academic staff, insufficient learning facilities, and as well disrupts academic calendars. This certainly created negative consequences for the majority of the Nigerian undergraduates' pragmatic competence in ESL writing as well. In addition to this, a research conducted by Okunrinmeta (2014) it was claimed that the majority of students' failed in their English examination at their pre-university examinations. He augmented that sociolinguistic factor in terms of gender variance; the ethnic; the multilingual and the socio-cultural settings paved the way for proper instruction with the medium of Standard British English (SBE) in an ESL classroom.

In view of the relative importance of ESL writing in the Nigerian context, Bdliya (2014) examined the degree to which language errors manifest among the Nigerian ESL learners. He conducted an experiment among the students' originating from a minority ethnic group known as Bura, in Nigeria. His findings indicated that $78 \%$ of the errors 
made by the ESL learners were grammatical in the form of tenses, omission, and concords. In the study, he justified this by citing:

The SSCE June/July results demonstrated that in 2009, out of the 1,200,398 candidates who enrolled, just $273,279(22.74 \%)$ had one credit or more. In $2010,1,143,169$ students' were enrolled to have enlisted, yet, just 245,890 (21.52\%) had one credit or more, while in 2011, 1,190,393 registered, however, just 265,896 (22.34\%) had one credit or more (Bdliya, 2014, p. 3).

\section{METHOD}

In this study, we adjusted the type of descriptive design, utilising the explanatory mixedmethod; i.e., the sequential configuration of the QUAN-Qual model (Creswell, 2014; Gay, Mills, \& Airasian, 2012). This furnishes us with the aptitude to give measurable predictors that statistically explain the Nigerian undergraduates' pragmatic competence as far as their gender variation. In this respect, the qualitative results subsequently refine, extend, and clarify the kinds of socio-pragmatic factors that play crucial roles in constraining most of the Nigerian undergraduates' pragmatic competence in ESL writing skills (Dörnyei, 2011; Tavakoli, 2012).

\section{Research Sampling}

Working within the traits of explanatory mixed-method, we first employed convenience sampling to select the representatives of the quantitative part. In practice, the sample covers 201 male and 201 females. This makes a snowballing of 402 representatives of a public university that was established in Kano; a city situated in the northern part of Nigeria. They are in their second year (Level 2) of university studies at the 2014/2015 academic session. Afterwards, using the criterion for maximum variation type of purposive sampling, twelve (12) informants out of the 402 representatives were selected for a focus group interview. This is to refine, extend, and clarify the kinds of sociopragmatic factors that play crucial roles in constraining their pragmatic competence in ESL writing skills based on gender variation (Creswell, 2014; Gay, et al., 2012).

\section{Research Instruments}

Two types' instruments were developed for this study, which were the descriptive essay question (DEQ) and Focus Group Interview Questions (FGiQ). The descriptive essay question required all the 402 representatives to describe their university based on its structural buildings, roads, and the serene of the university environments of their choice. They were asked to vividly depict Bayero University, Kano in 450 to 500 words and within the time expiration of $1 \mathrm{hr}, 30$ minutes. In the process, we monitored their writing session. And they were not permitted for any type of reference material, including dictionaries, or their smartphones. Upon completion, all the written essays were instantly collected. Whereas, the focus group interview questions focused towards understanding the factors that made some of the Nigerian undergraduates to attain a higher mean score and the others to attain lower mean scores in the process of the descriptive essay writing (Gay, et al., 2012). In this case, we selected six ESL learners' whose essays were rated 
with less level of language errors (three males and three females) and six ESL learners' who obtained the higher number of language errors (three males and three females).

\section{Research Procedures}

The quantitative data were analysed using the independent samples t-test to answer research question i-iv. This statistical guide to significant determines the probability level of the Nigerian undergraduates' gender variation in terms of their pragmatic competence in ESL writing skills (Creswell, 2014; Dörnyei, 2011; Tavakoli, 2012). In the other way, research question-v was analysed using the pattern of thematic analysis. Qualitatively, the interviews were transcribed into texts. It employs open, axial, and selective coding to identify the core categories of factors that constraint majority of Nigerian undergraduates pragmatic competence in ESL writing skills (Newby, 2014).

\section{Validity and Reliability}

In order to sustain the validity of the scoring process, the descriptive essays were handed over to an English lecturer; who is a Ph.D. holder, with more than ten years of teaching experience at the university to cypher the undergraduate's language errors using specific codes as the external rater. After this, again, in order to enhance the reliability of his grading, the scored essays were vetted over by an English Professor; which he acknowledged to be reliable and can be utilised in this study positively. The external rater focuses on language errors duly committed by the undergraduates in the areas of:

\section{Mechanical Structure Errors (MSE) \\ Grammatical Function Errors (GFE) \\ Sentence Structure Errors (SSE)}

Prior to this study a pilot study was conducted in order to obtain the validity and reliability of the essay question and the focus groups interview questions. 30 undergraduates' participated and the findings of the pilot study indicated that the instruction was clear and the students' did not encounter any problem with the question. To obtain the validity of the essay test, two English Professor's from Bayero University, Kano, Nigeria (BUK) verified and accepted the questions to be suitable for this study.

\section{FINDINGS AND DISCUSSIONS}

\section{Research Question 1}

Is there any significant difference in the overall mean scores for language errors found in the students' descriptive writing according to gender?

Table 1

The undergraduate's t-test results of the overall mean scores according to gender and the level of significance

\begin{tabular}{llllllll}
\hline Group & $N$ & Mean & SD & Mean Diff. & T-value & $d f$ & $p$ \\
\hline Females & 201 & 34.84 & 8.12 & -3.40 & -4.70 & 400 & .000 \\
\cline { 1 - 5 } Males & 201 & 31.44 & 6.25 & & & & \\
\hline
\end{tabular}


Regarding, the first major goal of this question, Table 1 reveals the findings of the independent samples t-test, which compares the language errors made by the male and female undergraduates' in their descriptive ESL writing. These findings suggested that the females were less pragmatically skilled, as they have committed more of language errors in the ESL writing (Mean=34.84, $\mathrm{SD}=8.12$ ), compared to the males matching (Mean $=31.44, \mathrm{SD}=6.25$ ). Therefore, the t-test of this situation indicated that there was a statistically significant difference $(\mathrm{t}=-4.70$, Mean diff. $=-3.40, \mathrm{df}=400, \mathrm{p}=.000)$. The male undergraduates showed a relatively higher degree of pragmatic skills compared to the females, which indicated that they were more competent than the females.

In this sense, our results in this segment can be related to that of Adogwa (1992), Ojetunde (2013), Ololube, et al., (2013), and Bdliya (2014) at instances where they affirm that the majority of the Nigerian ESL learners' finds it very difficult when it comes to justify their knowledge in terms of pragmatic skills in ESL writing. Their results indicated that most of the Nigerian ESL learners' could not trigger the desired basic linguistic knowledge required. Needless of them to extend in conveying extra-linguistic features were needed for meaning making in ESL writing. In a general sense, this finding also goes in accordance with the affirmation of Muhammad and Subadrah (2015) who insists that male students more cautious about their ESL writing than the female students.

\section{Research Question 2}

Is there any significant difference for language errors found in the use of mechanical structure in the students' ESL writing according to gender?

Table 2

The undergraduates' t-test results comparing the gender variation for mechanical structure errors and the level of significance

\begin{tabular}{llllllll}
\hline Group & $N$ & Mean & $S D$ & Mean Diff. & T-value & $d f$ & $p$ \\
\cline { 1 - 6 } Females & 201 & 18.40 & 5.71 & -2.42 & -4.56 & 400 & .000 \\
\cline { 1 - 5 } Males & 201 & 15.98 & 4.92 & & & & \\
\hline
\end{tabular}

Practically, the utilisation of mechanical structures proves to be crucial among Nigerian undergraduates' in ESL writing. Relatively, Table 2 shows that we have conducted an independent samples t-test to compare the undergraduates' mean scores in terms of mechanical errors committed in the descriptive ESL writing. In this connection, we found that there was a significant difference in the mechanical errors committed. The female students' achieved a higher means (Mean=18.40, $\mathrm{SD}=5.71$ ), which indicated they commited more of language errors in the area of mechanical structure compared to the males' (Mean=15.98, SD=4.92). In this context, the results of the t-test clearly indicate that the female students' significantly commit more of mechanical writing errors than the male students $(\mathrm{t}=-4.56$, Mean diff. $=-2.42, \mathrm{df}=400, \mathrm{p}=.000)$.

As can be seen as well, these findings indicated that the females commit more of language errors within the scope of mechanical errors, mainly, in the use of punctuation marks, including the apostrophe, commas, full stops, semicolon, question marks, and in the capitalisation issues. In addition to this, a mechanical structure in this study looks into their level of accuracy in spelling features, including omitting the forms of vowels and or consonants, doubling circumstances and capitalisation problems. Our findings symbolise as 
well that the females commit more of the mechanical errors as they failed to control their pragma-linguistic skills for an effective representation. This indicates that the females failed to identify the basis of mechanical errors which signified their low level of pragmatic competence in ESL writing compared to the males. In this category, our findings could be related to that of Adogwa (1992), Ojetunde (2013) and Bdliya (2014). Their studies reported that most of the Nigerian ESL learners' could not coherently and cohesively write an accurate essay. Their results further affirmed that their ESL writing was overflowing with very limited knowledge in the use passive forms and were greatly deficient in structuring mechanical rules required for a competent ESL writing.

\section{Research Question 3}

Is there any significant difference for language errors found in the use of grammatical functions in the students' ESL writing according to gender?

Table 3

The undergraduate's t-test results comparing the gender variation for grammatical function errors and the level of significance

\begin{tabular}{llllllll}
\hline Group & $\mathrm{N}$ & Mean & SD & Mean Diff & T-Value & df & p \\
\cline { 1 - 5 } Females & 201 & 8.28 & 2.10 & -.134 & -.666 & 400 & .283 \\
\cline { 1 - 5 } Males & 201 & 8.14 & 1.93 & & & & \\
\hline
\end{tabular}

In the same way, Table 3 indicated that we explored the Nigerian undergraduates' ESL writing, so as to identify the level of language errors in the use of grammatical functions. The analysis of the independent samples t-test indicates that the Nigerian female ESL learners commit more errors than the male ESL learners in the use of grammatical function's components. The female Nigerian undergraduates committed more errors (Mean=8.28, $\mathrm{SD}=2.10$ ) which were relatively higher compared to the male ESL learners (Mean=8.14, $\mathrm{SD}=1.93$ ) and the t-test showed that the difference was not statistically significant $(\mathrm{t}=-.666$, Mean diff. $=-.134, \mathrm{df}=400, \mathrm{p}=.283)$.

\section{Research Question 4}

Is there any significant difference for language errors found in the use of sentence structures in the students' ESL writing according to gender?

Table 4

The undergraduate's t-test results comparing the gender variation for sentence structure errors and the level of significance

\begin{tabular}{llllllll}
\hline Group & $N$ & Mean & SD & Mean Diff. & T-value & $d f$ & $p$ \\
\hline Females & 201 & 8.15 & 2.23 & -.840 & -4.01 & 400 & .000 \\
\cline { 1 - 5 } Males & 201 & 7.31 & 1.95 & & & & \\
\hline
\end{tabular}

Table 4 revealed that we performed an independent samples t-test to compare the Nigerian undergraduates' mean scores in terms of language errors committed in their utilisation of sentence structure according to gender. We found that the females once more achieved a higher mean (Mean=8.15, SD=2.23). This indicate they committed high rate of sentence structure errors compared to the males (Mean=7.31, $\mathrm{SD}=1.95$ ). Results of the independent samples t-test indicated that sentence errors committed by females were significantly higher than the males $(t=-4.01$, Mean diff. $=-.840, \mathrm{df}=400$, $\mathrm{p}=.000)$. 
In this study, sentence structures relate to the proper utilisation of simple, compound and complex sentences (Ifantidou, 2014; Sarfraz, 2011; Owu-Ewie \& Lamotey, 2016). Primarily, here, our findings go in conformity with that of Kamal (2004), Bodunde and Sotiloye (2013), as well as that of Kibar and Akkoyunlu (2016). They critically affirm that the majority of university undergraduates' indulge into language errors in terms of sentence formation, due to lack of proper instruction style. With such a state of affairs, certainly, it proves to be difficult among Nigerian undergraduates to avoid utilisation of run-on sentences, incomplete sentences and repetitiveness in ESL writing (Bdliya, 2014; Okunrinmeta, 2014). And this diminishes their pragmatic competence in ESL writing.

Research Question 5

What are the factors that made the majority of the Nigerian undergraduates to the lack of pragmatic competence, which facilitates their language errors in ESL writing?

In answering research question $\mathrm{v}$, this study employs thematic procedural analysis in transcribing, coding, identifying and reporting the emerging themes recognised from the focus group interview session (Creswell, 2014; Dörnyei, 2011; Newby, 2014). In simple terms, open coding was applied to identify the emerging themes. After that, axial coding was employed in finding the theme's consistency. Then, selective coding was utilised in identifying the core categories of factors that constrain the majority of the Nigerian undergraduates' pragmatic competence in ESL writing skills. By so doing, this study identified three core-themes, along with six sub-themes relating to consistent factors that constraint most of the Nigerian undergraduates ESL writing skills. And these are summarised and presented in Figure 2 below:

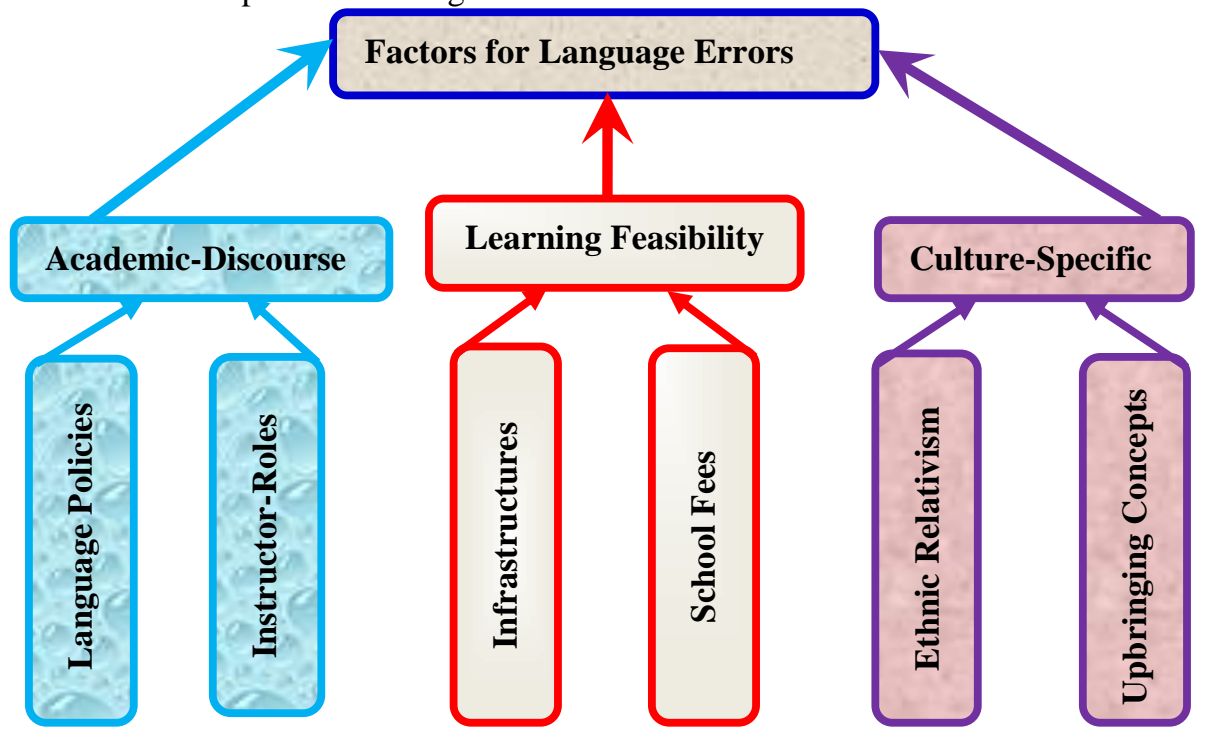

Figure 2

The identified core-themes and sub-themes factors that constrain Nigerian undergraduates ESL writing skills 
In conformity, this study identifies the major themes within the scope of culture-specific, learning feasibility and academic discourse as the major factors that made the majority of the Nigerian undergraduates commit language errors in ESL writing. Regarding this issue, the voices of the majority of the respondents have acknowledged their lack of pragmatic competence to the acclaimed national language policies. Their voices pointing that language policies did not favour their academic discursive entity in the sense the policies failed to identify the proper way of conceptualising their academic discourse. On this issue, one of the respondents has this to share:

The Nigerian policies have failed to provide us linguistic inferences on ESL writing skills (pause) in a multi-cultural country like Nigeria right from primary and secondary school days there is less concentration on developing writing skills (pause) you see many of us are now facing problems (RESP. 5; Male).

This can be supported with the affirmations of Adogwa (1992), Kamal (2004), Garba (2013), and Francis (2015) whose claims on the Nigerian national language policies were last modified in the year 2004. On the contrary, such acclaimed remodified policies lack current linguistic intricacies and effectiveness as they are mere replication of the officially produced by Federal Promulgation Decrees of 1981 and 1979. This is the sort of dilemma, which they affirm on classroom teaching do not give more emphasis on pragmatic development towards ESL writing competence. Specifically, this can further be related to an instance where Kamal (2004) strengthen that pragmatic development in ESL writing are "only taught to students' who are English single honours and they simply reflect a fraction of total ESL learners' across the Nigerian universities" (p. 162).

Another vital case the majority of the respondent stresses is that they lack dedicative instructors to teach them in higher education. They were also deprived of good English teachers at primary and secondary levels and this played crucial roles towards their poor performance in ESL writing. The failures of the government in providing dedicative qualified, qualitative instructors in secondary school and tertiary learning have affected their ESL writing skills. Going along these views, in the focus group interview session, one of the respondents has this to share with us:

I would say students should improve on their hard work, but the Government should employ dedicative and qualified teachers (pause) at times (changes expression) I don't know what my lecturers are saying (pause) they are weak graduate and you don't have enough and you want to impart on others how? Beside that some are not committed, so (pause) wallahi (I swear) it is really affecting everybody (pinpointing towards other session members) like him, me and even her, that girl over there and that girl over there (RESP. 9; Female).

This could be attributed with an attestation made by Llach (2011) that the frequent appearance of language errors in students' ESL/EFL writing signifies "failure either in the process of learning or in the process of teaching" (p. xii). Supposedly, at their current university level, they need to be synthesised and to analytically master the use of "morphemic built up in the combination of words, and or in the use of auxiliaries" 
(Garba, 2013, p. 22) in order to attain accurate learning feasibility. In addition to this, such type of problem on learning feasibility is further attested by one of the informants:

These things depends on the government and the academic body of private schools (pause) they should employ teachers that are specialised in every aspect of learning, because (pause) you see only one English teacher on a whole school taking all English lessons (reflecting pre-university experience) he will take the junior and senior classes (pause) he takes everything whereas that is not his specialised areas (pause) the academic body of the private school go only worry about school fees, not the quality of teaching (RESP. 3; Male).

Some of the informant's views on the culture-specific concepts within the society in which they have grown are not restricted to one language, one ideology, one culture and one socio-culture befitting their status and position. In other words, the multi-ethnic and multi-linguistic contexts of Nigerian do not permit them to attain competency in ESL writing. Due to this ethnic relativism, the majority of Nigerian undergraduates' lacks societal motivation and parental guide that will enhance their ESL writing not necessarily in the schools. In reality, some of them further shares:

You see (pause) I hardly write English (pause) at home we speak Igbo. You see I frequently write in my dialect (pause) ohm, I turn to my dialect especially when I am with my family (pause) and normally if not for school I don't practice writing in English. Even outside I chip-in my language (pause) ha-ha (laugh), most time even in my social media Facebook or in a tweet I am that a type of person (pause) Igbo must be there (RESP. 10; Female).

No! (pause) I don't think gender difference could hamper students writing (pause) the problem is the upbringing (pause) and location where one grown up (pause) ah! (pause) ohm (pause) environment matters a lot, ..., all they do is to communicate with me in my own local dialect (pause) only. So (pause) it hampers my writing in English (RESP. 12; Female).

From this extract, it can be concluded that the majority of the Nigerian undergraduates hardly practice improving their ESL writing competence except on the classroom basis. It is clear that there is a lack of counselling on the part of the parents in developing homely strategies that will facilitate the Nigerian learners ESL writing competency. This goes for the societal fear for the death of their mother tongue (MT). Hence, the reason behind the societal intuition is due to fear of native language extinction. The majority of the traditionalists are the views that if they should support their children to be competent enough in ESL, in turn, the kids will abandon their cultures, their native languages, and their heritage. Clearly, the societal and parental love for mother tongue (MT) hampers their pragmatic development in ESL writing.

\section{Implications of the Study}

Practically, the quantitative analysis is situated based on their gender variation, which has provided us with their level of statistical variation in committing language errors. This duly provides us with the possibility to imply on the best ways that would build 
their ESL writing skills on the basis of the pragma-linguistic competence. Thus, the discoveries in this study are additionally cheerful to serve as a directing standard to the Nigerian Ministry of Education (NME), the National Policy on Education (NPE), the Nigerian Universities Commission (NUC), and the National Institute of Nigerian Languages, Aba (NINLAN), as well as the United Nation Children Fund (UNICEF). By implication, these national and international bodies should take the charge of mandating and supporting the creation of strategic writing centres particularly at the universities and in other to the tertiary levels. In this manner, the centres would centralise, specifically in identifying the Nigerian ESL learners weaknesses; thereby, integrating their competence in ESL writing.

Moreover, not alone the students'; even the instructors require training sessions to facilitate and promote their teaching strategies with students' for proper knowledge implementation. This assertion was also pointed by Subadrah, Mohamed, and Marimuthu (2014) arguing that teacher trainee programme enhances and creates sustainability of instruction strategies in terms of content learning which facilitates their efficiency through cultural and relevant to impart knowledge to learners'.

All the more, the qualitative analysis goes with respect to the socio-pragmatic competence level. Here, the national and worldwide bodies, like those of the African and American Women's Association (AAWA), the Nigerian Organisation of Women (NOW), the International Labour Organisation (ILO), the Women Farmers Advancement Network (WOFAN), and the Education for all (EFA) ought to set up solid principles and systems that will encourage Nigerian female students' ESL writing. These bodies should provide conceivable financing and other strong means where distinctive strategies can be utilised for the smooth advancement of the undergraduates' competence in ESL writing. And this can be carried out through cognitive, implicit-task, concept-learning strategies and or through constructivist, competitive team-based, audio-visual and cooperative learning strategies. In truth, and practically, unless, Nigerian female students' are competent enough in their ESL writing, which in so doing, these associations can likely accomplish their sought objectives. Thus, support and aids by these organisations will make universities a better place to inculcate atmospheric spheres for a sustainable future for academic excellence. Therefore, such associations should also embark on supporting and providing funds for developing such kind of strategies to pragmatically develop specifically female students' competency in ESL writing and also the male students' competence in ESL writing in general.

\section{Limitation and Recommended Future Studies}

Based on its conception, this study has some limitations; because the Nigerian undergraduate samples were employed in a single public university situated within the northern Nigerian axis. As such, more studies should be carried out in other universities within the axis of the south, east, and the west part of Nigerian to explore undergraduates ESL writing competence. Future studies should also focus on the Nigerian ESL learners' writing at the primary, the secondary, colleges, polytechnics, and other higher institutional levels. 
Moreover, the present study only focuses on undergraduates ESL writing skills variation according to their gender; as it employed only the inferential t-test type of descriptive analysis of the quantitative data. As such; future researchers should explore students' ESL writing using other forms of statistical procedures to identify their variation according to their ethnic groups, academic disciplines, identity, language background, sociocultural, and socioeconomic situations.

This study only employs a descriptive type of essay writing to investigate their variation competence in ESL writing. As such, future studies should employ the augmentative, expository, narrative, and another type of essay writing formats like letter writing, abstract, and even academic writing essay types, to explore Nigerian undergraduates' ESL writing skills. Moreover, it could only utilise the convenience and the purposive sampling technique to generate its findings; therefore more studies should be done using other types of sampling procedures. As the case may, this study employed a thematic type of analysis, using the open coding, axial coding, and specific coding to analyse the transcribed qualitative data. Thus, future studies can employ content, narrative, or even software analysis like NVIVO and other procedures of qualitative data analysis.

\section{CONCLUSION}

Based on the findings illustrated in this study, it can be agreed that the majority of the Nigerian undergraduates faces challenges in terms of pragmatic competence that guide their skills in ESL writing. Perhaps, this might be attributed to their ignorance of sociopragmatic and pragma-linguistic practices in ESL writing skills. Fundamentally, the results from the quantitative analyses of language errors committed by the Nigerian undergraduates in ESL writing indicate that the females commit more errors than the males. Unfortunately, 50\% of the sampled undergraduates' in this study performed poorly in the ESL writing and the majority of whom belonged to the female category. They showed a lack of pragmatic competence in the use of writing mechanics, grammar, and in structuring sentences. Thus, they showed limited acquaintance to the pragmatic knowledge that hindered their pragma-linguistic and socio-pragmatic fluency in ESL writing. In such manner, problems pertaining to their indulgence to language errors in ESL writing could be ascribed to influence in terms of cultural specification, learning aspects, and the academic situations. These agonies have put the majority of the Nigerian undergraduates in dire straits to the mastery of linguistic rules associated with ESL writing skills. It is hoped that more studies would be conducted using a descriptive essay writing strategy of exploration within the scope of applied linguistics, education, and beyond towards enhancing ESL learners competence in writing skills. Therefore, more studies should be carried out in pragmatic competence among Nigerian ESL learners, in order to come up with a viable remedy to improve their ESL writing skills. 


\section{REFERENCES}

Abegunde, B. (2014). Gender inequality: Nigerian and international perspectives. British Journal of Arts \& Social Sciences, 17(1):165-191.

Adogwa, T.O. (1992). A comparative study of grammatical and discourse errors of senior secondary three and first-year undergraduate students. Unpublished masteral thesis. Ahmadu Bello University, Zaria, Nigeria.

Babalola, J.O. \& Oyinloye, G. (2012). Language and gender distinctions. International Review of Social Sciences and Humanities, 2(2):236-242.

Bdliya, I.M. (2014). Error analysis of passive transformation and its pedagogical implications: A case study of selected Bura learners of English. Unpublished doctoral thesis. Ahmadu Bello University, Zaria, Nigeria.

Bodunde, H.A. \& Sotiloye, B.S. (2013). A critique of undergraduate students writing skills in an ESL setting: Sample from the Federal University of Agriculture Abeokuta, Nigeria. World Journal of English Language, 3(2):10-21.

Chomsky, N. (1965). Aspects of the theory of syntax. Cambridge, MA: M.I.T. Press.

Coates, J. (2015). Women, men, and language: A sociolinguistic account of gender differences in language. Routledge Publishing.

Creswell, J.W. (2014). Educational research: Planning, conducting and evaluating quantitative and qualitative research, $4^{\text {th }}$ edition, Boston: Pearson Publishing.

Crystal, D. (1985). A dictionary of linguistics and phonetics. Blackwell: Oxford Publishing.

Cui, Z. \& Tae-Ja, P. (2013). An analysis of errors in English writing made by Chinese and Korean university students. Theory and Practice in Language Studies, 3(8):1342-1351.

Dörnyei, Z. (2011). Research Methods in Applied Linguistics: Quantitative, qualitative and mixed methodologies, New York: Oxford University Press.

Francis, D.I. (2015). Solving the problem of poor quality of university graduates in Nigeria: A proposed holistic approach. British Journal of Education 3(7):52-70.

Garba, M.I. (2013). Sentence maintenance in essay writing: A case study of students' essay writing in six selected senior secondary schools in Kano state. Unpublished masteral thesis. Bayero University, Kano, Nigeria.

Gay, L.R., Mills, G.E., \& Airasian, P.W. (2012). Educational research: Competencies for analysis and application, $10^{\text {th }}$ edition. Boston, U.S.A: Addison-Wesley Publishing.

Grabe, W. \& Kaplan, R.B. (2014). Theory and practice of writing: An applied linguistic perspective. Routledge Publishing.

Gumperz, J.J. \& Cook-Gumperz, J. (1982). Introduction: Language and the communication of social identity. Language and Social Identity, 1-21.

Hymes, D. (1972). On communicative competence. In J.B. Pride \& J. Holmes (Eds.), Sociolinguistics, p. 269-293. Harmondsworth: Penguin Publishing. 
Ifantidou, E. (2014). Pragmatic competence and relevance. Amsterdam: John Benjamins Publishing Company.

Kamal, A. (2004). Writing academic English in an ESL situation: A case study of students' of Bayero University, Kano. Unpublished doctoral thesis. Bayero University, Kano-Nigeria.

Kibar, P.N. \& Akkoyunlu, B. (2016). University students' visual cognitive styles with respect to majors and years. Eurasia Journal of Mathematics, Science \& Technology Education, 12(2):321-333.

Lazenby, H. (2016). What is equality of opportunity in education? Theory and Research in Education, 1-12.

Leech, G. (1983). Principles of pragmatics. New York: Longman Publishing.

Llach, M.A.S (2011). Lexical errors and accuracy in foreign language writing. Toronto: Multilingual Matters Publishing.

Mojabi, S.S. (2014). Correlation between grammatical competence and pragmatic competence among Iranian university EFL learners. Unpublished masteral thesis. University Malaya, Kuala Lumpur, Malaysia.

Muhammad, A.S. \& Subadrah, M.N. (2015). An analysis of descriptive essay writing among Nigerian undergraduates: An analysis of variance in English writing skills. Australian Journal of Basic and Applied Sciences, 9(37):323-329.

Ojetunde, A.F. (2013). Lexico-grammatical errors in Nigerian English: Implications for Nigerian teachers and learners of English. European Scientific Journal, 9, (17):252-268.

Okunrimeta, U. (2014). Syntactic and lexico-semantic variations in Nigerian English: Implications and challenges in the ESL classroom. Open Journal of Modern Linguistics, 4:317-332.

Ololube, N.P., Agbor, C.N., \& Uriah, A.O. (2013). Vicious hazard to peace culture in tertiary education: the activities of the secret cults. British Journal of Education, Society \& Behavioural Science, 3(1):65-75.

Owu-Ewie, C., \& Lomotey, C. F. (2016). L1 (Akan) interference errors in L2 (English) writing: the case of three junior high school students in Ghana. American Journal of Language and Literacy, 1: A1-A18.

Sarfraz, S. (2011). Error analysis of the written English essays of Pakistani undergraduate students: A case study. Asian Transactions on Basic and Applied Sciences, 1(3):29-5.

Sawalmeh, M.H.M. (2013). Error analysis of written English essays: The case of students of the preparatory year programme in Saudi-Arabia. English for Specific Purposes World, 40(14):1-17. 
Subadrah, N., Mohamed, A.R. \& Marimuthu, N. (2013). Malaysian teacher trainee' practices on science and the relevance of science education for sustainability. International Journal of Sustainability in Higher Education, 14(1):71-89.

Williams, J. (2005). Writing centre interaction: Institutional discourse and the role of the peer. Interlanguage Pragmatics: Exploring Institutional talk, 37-66. London: Lawrence Erlbaum Associates, Publishers.

\section{Turkish Abstract \\ Nijeryalı Lisans Öğrencilerinin Betimleyici ESL Yazmadaki Dil Hatalarını Pragmatik Olarak Değerlendirme}

$\mathrm{Bu}$ çalışma Nijeryalı lisans öğrencileri arasındaki ELS yazma becerilerini pragmatik yeterlik düzeyinde incelemektedir. Yöntem olarak betimleyici araştırma deseni nitel-nicel model (QUANQual model) ile açıklanmıştır. Ölçüm araçları betimleyici bir yazı metni ve odak grup görüşmesi sorularıdır. Betimleyici yazı yazma etkinliğine uygun örnekleme yöntemiyle seçilmiş toplam 402 lisans öğrencisi katılmıştır. Verilere nicel bağımsız t-testi uygulanmıştır. Sonuçlar erkek öğrencilerle karşılaştırıldığında kız öğrencilerin dil hatalarında daha yüksek bir ortalama elde ederken pragmatik yeterliklerini geliştirmede daha fazla güç harcadıklarını göstermektedir. Buna ek olarak kız öğrencilerin t-testi değerleri onların gramer, dilbilgisi ve cümle yapıs1 becerilerindeki pragmatik beceri eksikliklerinin dili yorumlamada hata yapmalarına sebep olduğunu göstermektedir. Nitel olarak amaçlı örnekleme ile seçilen 402 lisans öğrencisinden rastgele olarak 12 öğrenci odak grup görüşmesi için belirlenmiştir. Görüşme seanslarına göre kültürel yenilik, öğrenme esnekliği ve akademik söylem çoğu Nijeryalı lisans öğrencilerinin özellikle kız öğrencilerin ELS yazma becerilerini kısıtlayan anahtar ögeler olarak ön plana çıkmıştır. Böylece, bu çalışma Nijeryalı lisans öğrencilerinin ELS yazma becerilerindeki pragmatik yeterliğin nasıl geliştirileceğine yönelik sonuçlar ortaya koymaktadır.

Anahtar Kelimeler: ELS yazma, pragmatik yeterlik, cinsiyet farklılığı, dil hataları, Nijeryalı lisans öğrencileri, betimleyici metin yazma

\section{French Abstract \\ Évaluation de Compétence Pragmatique dans les Erreurs de Langue d'Étudiants en licence nigérians dans Écriture d'ESL Descriptive}

Cette étude examine sur le niveau de compétence pragmatique pour ESL l'écriture de compétences parmi des étudiants en licence nigérians. Méthodologiquement, il adopte le design de recherche descriptif dans le cadre explicatif du modèle de QUAN-QUAL. Les instruments utilisés sont le texte d'essai descriptif et des questions d'entretien de groupe de discussion. Par écrit les essais descriptifs, un total de 402 étudiants en licence participés par échantillonnage de commodité. Quantitativement, un t-test d'échantillons indépendant a été effectué. Les résultats indiquent que les femelles exigent la mise de plus d'efforts vers l'amélioration de leur compétence pragmatique dans l'ESL écrivant comme ils ont réalisé des moyens plus hauts pour des erreurs de langue, comparées à celui des mâles. De plus, la valeur de t-test a manifesté que les femelles manquent de compétences dans les compétences pragmatiques de structure mécanique, la fonction grammaticale et des structures de phrase et ceci les a faits commettre plus d'erreurs de langue. Qualitativement, un entretien de groupe de discussion a été tenu aléatoirement avec 12 participants des 402 étudiants en licence par l'échantillonnage résolu. Les résultats des sessions 
d'entretien révèlent les nouveautés de spécifiques à culture, apprenant la faisabilité et le discours universitaire comme les éléments clés que la contrainte la plupart des étudiants en licence nigérians ESL l'écriture de compétences, particulièrement les femelles. Donc, cette étude révèle des implications fortes sur la façon du mieux développer la compétence pragmatique des apprenants nigérians dans ESL l'écriture de compétences.

Mots Clés: ESL écriture, compétence pragmatique, variation de genre, erreurs de langue, étudiants en licence nigérians, écriture d'essai descriptive

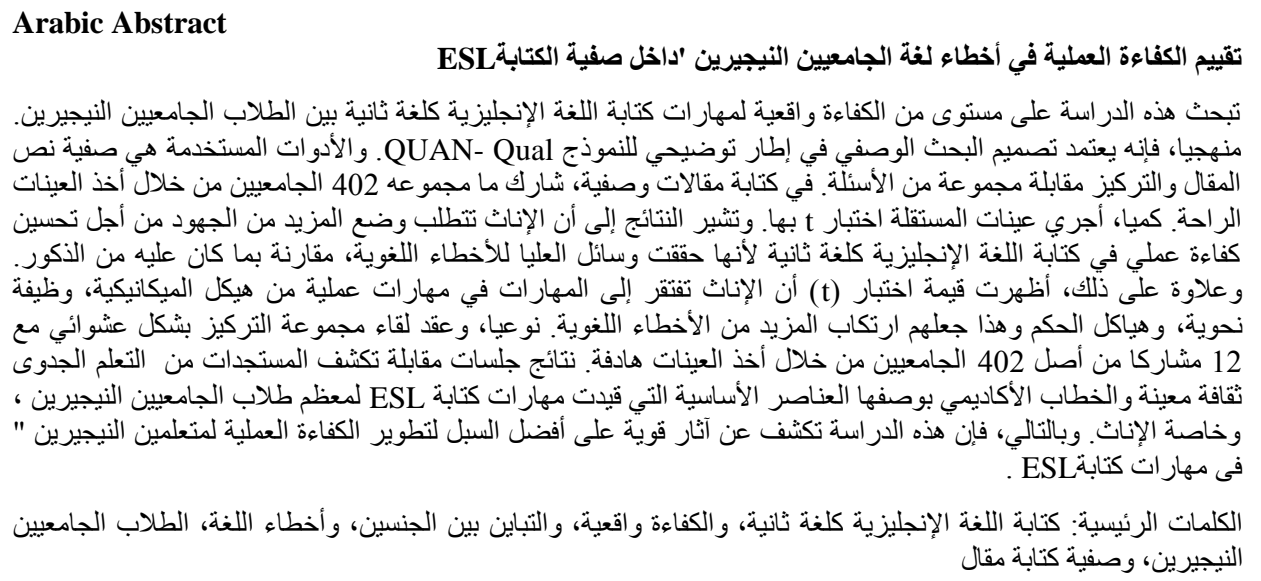

\section{German Abstract}

Auswertung der pragmatischen Kompetenz in sprachlichen Fehlern der nigerianischen Studenten in der beschreibenden EZS-Schrift

Diese Studie untersucht auf der Ebene der pragmatischen Kompetenz für EZS schriftlich Fähigkeiten unter nigerianischen Studenten. Methodisch beschreibt es deskriptives Forschungsdesign im erklärenden Rahmen des QUAN-Qual-Modells. Die verwendeten Instrumente sind deskriptive Aufsatztext- und Fokusgruppen-Interviewfragen. Im Schreiben der beschreibenden Aufsätze, insgesamt 402 Studenten absolvierten durch Bequemlichkeit Probenahme. Quantitativ wurde ein unabhängiger Proben-t-Test durchgeführt. Die Ergebnisse deuten darauf hin, dass die Frauen benötigen mehr Anstrengungen zur Verbesserung ihrer pragmatischen Kompetenz in der EZS schriftlich, da sie ein höheres Mittel für Sprachfehler, im Vergleich zu denen der Männer erreicht. Darüber hinaus zeigte der t-Test Wert, dass die Frauen keine Fähigkeiten in der pragmatischen Fähigkeiten der mechanischen Struktur, grammatische Funktion und Satzstrukturen und dies machte sie begehen mehr Sprachfehler. Qualitativ wurde ein Fokusgruppen-Interview nach dem Zufallsprinzip mit 12 Teilnehmern aus den 402 Studenten durch gezielte Probenahme durchgeführt. Die Ergebnisse der Interview-Sessions zeigen Neuheiten der kulturspezifischen, Lernfähigkeit und den akademischen Diskurs als die wichtigsten Elemente, die die meisten der nigerianischen Studenten, die EZS schriftlich Fähigkeiten, vor allem die Frauen einschränken. Daher zeigt diese Studie starke Auswirkungen auf, wie am besten zu entwickeln pragmatische Kompetenz der nigerianischen Lernenden in EZS schriftlich Fähigkeiten.

Schlüsselwörter: EZS-schreiben, pragmatische kompetenz, geschlechtsspezifische unterschiede, sprachfehler, nigerianische studierende, deskriptive aufsätze 


\section{Malaysian Abstract \\ Menilai Kecekapan Pragmatik dalam Kesilapan Bahasa Nigeria Mahasiswa dalam Penulisan Deskriptif ESL}

Kajian ini menyiasat kepada tahap kecekapan pragmatik untuk kemahiran menulis ESL dalam kalangan pelajar Nigeria. Metodologi, ia menerima pakai reka bentuk penyelidikan deskriptif dalam rangka kerja penerangan daripada model QUAN-Qual. Instrumen yang digunakan adalah teks esei dan kumpulan fokus temu bual soalan deskriptif. Dalam menulis karangan deskriptif, seramai 402 mahasiswa mengambil bahagian melalui persampelan mudah. Kuantitatif, satu sampel bebas ujian-t telah dijalankan. Keputusan menunjukkan perempuan perlu meletakkan lebih usaha ke arah meningkatkan kecekapan pragmatik mereka secara bertulis ESL kerana mereka mencapai cara yang lebih tinggi untuk kesilapan bahasa, berbanding dengan lelaki. Selain itu, nilai ujian-t menunjukkan bahawa wanita kurang mahir dalam kemahiran pragmatik struktur mekanikal, fungsi tatabahasa, dan struktur ayat dan ini mengakibatkan mereka melakukan lebih banyak kesilapan bahasa. Kualitatif, temu bual kumpulan fokus telah diadakan secara rawak dengan 12 peserta daripada 402 mahasiswa melalui persampelan bertujuan. Keputusan sesi temuduga mendedahkan kemungkinan pembelajaran dan wacana akademik sebagai unsur-unsur utama yang menjadi kekangan kebanyakan pelajar Nigeria dalam kemahiran menulis ESL, terutamanya perempuan. Oleh itu, kajian ini mendedahkan implikasi yang kuat mengenai cara terbaik untuk membangunkan kecekapan pragmatik pelajar Nigeria 'dalam ESL kemahiran menulis.

Kata Kunci: penulisan ESL, kecekapan pragmatik, perubahan jantina, kesilapan bahasa, pelajar Nigeria, esei deskriptif

\section{Russian Abstract \\ Прагматическая Оценка Ошибок Нигерийских Студентов При Описательном Написании ESL (Английский Как Второй Язык)}

Это исследование посвящено изучению уровня прагматической компетенции для ESL навыков письма среди Нигерийских студентов. Методически, ето принимает описательный дизайн исследования в пояснительной рамках модели QUAN-Qual. Инструменты используемые описательные эссе текст и фокус-групп интервью вопросы. На написании описательных эссе, в общей сложности 402 магистрантов принимала участий с помощью выборки удобства. Количественно, независимый образцов Т-тест было проведено. Результаты показали самки требуется положить больше усилий к улучшению их прагматичную компетентности в ESL письменной форме как они достигли более высокого средства для ошибок языка, по сравнению с самцами. Более того, значение Т-тест показал, что у самок не хватало навыков в прагматических навыков механического состава, грамматической функции и структуры предложения и это сделало их совершать больше ошибок языка. Качественно, фокус-группы интервью было проведено в случайном порядке с 12 участниками из 402 студентов через преднамеренной выборки. Результаты интервью сессий показали новинки культуру конкретных, изучение технико-экономического и академический дискурс в качестве ключевых элементов сдерживающим большинство Нигерийских навыков студентов ESL письма, в частности женщин. Таким образом, это исследование показало сильное последствия на том, как лучше развивать прагматический компетентность Нигерийских учащихся в ESL навыков письма.

Ключевые Слова: ESL письма, прагматическая компетенция, гендерные различия, ошибки языка, нигерийские студенты бакалавриата, описательные эссе 